\title{
A new miniature Pristella (Actinopterygii: Characiformes: Characidae) with reversed sexual dimorphism from the rio Tocantins and rio São Francisco basins, Brazil
}

\author{
F.C.T. Lima, R.A. Caires, C.C. Conde-Saldaña, J.M. Mirande, and F.R. Carvalho
}

\begin{abstract}
A new species of the genus Pristella Eigenmann, 1908 (Pristella crinogi sp. nov.) is described from the middle rio Tocantins and middle rio São Francisco basins, Brazil. The new species can be diagnosed from its two congeners, Pristella ariporo Conde-Saldaña, Albornoz-Garzón, García-Melo, Villa-Navarro, Mirande, and Lima, 2019 and Pristella maxillaris (Ulrey, 1894), by a combination of color pattern and teeth morphology characters. A phylogenetic analysis of the genus recovered P. crinogi as the sister taxa of P. ariporo. Pristella crinogi, along with P. ariporo, are the first characiform fishes, and one of the first bony fishes, to be reported as presenting a reversed sexual dimorphism, with females presenting a more developed color pattern than males. Comments on the miniaturization of the species, as well as remarks on the biogeography of the genus Pristella, are presented.
\end{abstract}

Key words: Pristella crinogi, Pristella ariporo, Pristella maxillaris, Hyphessobrycon axelrodi, Hyphessobrycon micropterus, new species, taxonomy, phylogeny.

Résumé : Une nouvelle espèce de genre Pristella Eigenmann, 1908 (Pristella crinogi sp. nov.) est décrite des bassins versants du rio Tocantins moyen et du rio São Francisco moyen (Brésil). La nouvelle espèce se distingue de ses deux congénères, Pristella ariporo Conde-Saldaña, Albornoz-Garzón, García-Melo, Villa-Navarro, Mirande et Lima, 2019 et Pristella maxillaris (Ulrey, 1894), par une combinaison de caractères associés à la coloration et à la morphologie des dents. Une analyse phylogénétique du genre fait ressortir P. crinogi comme taxon-frère de P. ariporo. Pristella crinogi, ainsi que P. ariporo sont les premiers poissons characiformes et parmi les premiers poissons osseux pour lesquels un dimorphisme sexuel inversé est signalé, les femelles présentant une coloration plus développée que les mâles. Des commentaires sur la miniaturisation des espèces, ainsi que des remarques sur la biogéographie du genre Pristella sont présentés. [Traduit par la Rédaction]

Mots-clés : Pristella crinogi, Pristella ariporo, Pristella maxillaris, Hyphessobrycon axelrodi, Hyphessobrycon micropterus, nouvelle espèce, taxonomie, phylogénie.

\section{Introduction}

Pristella Eigenmann, 1908 was for a long time considered a monotypic genus, including only Pristella maxillaris (Ulrey, 1894) (x-ray tetra). The genus was defined as being similar to the genus Hemigrammus Gill, 1858, but presenting numerous minute conical teeth along the maxilla (Eigenmann 1908). Recently, Conde-Saldaña et al. (2019) described a second species for the genus, Pristella ariporo, from the río Orinoco basin in Colombia and, based on a broad phylogenetic hypothesis, redefined Pristella as being supported by 15 synapomorphies. However, the original character defining Pristella, the presence of numerous conical teeth along the maxilla, was identified as an autapomorphy of P. maxillaris because P. ariporo has an edentulous maxilla.

During a survey of the vertebrate fauna of the Estação Ecológica Serra Geral do Tocantins, a large protected area at the border of the upper rio Tocantins and rio São Francisco basins, states of Tocantins and Bahia, Brazil (Nogueira et al. 2011), in which two of the authors (F.C.T.L., R.A.C.) took part, a bright-colored, miniature characid fish was collected in a small tributary of the rio Preto, rio Tocantins basin. The species was immediately recognized as new and cited (as Hyphessobrycon sp. "vermelhinho") in an inventory of the ichthyofauna of the area (Lima and Caires 2011). Subsequent collections undertaken by C. Oliveira and collaborators in the region obtained additional material of the species. The present contribution aims at describing this new species and discussing some of its uncommon morphological features.

\section{Materials and methods}

Measurements and counts were taken according to Fink and Weitzman (1974) and Menezes and Weitzman (1990), with the

Received 8 October 2020. Accepted 20 December 2020.

F.C.T. Lima. Museu de Zoologia da Universidade Estadual de Campinas “Adão José Cardoso”, Caixa Postal 6109, 13083-683, Campinas, SP, Brazil. R.A. Caires. Seção de Peixes, Museu de Zoologia da Universidade de São Paulo, CEP 04263-000, São Paulo, SP, Brazil.

C.C. Conde-Saldaña. Departamento de Morfologia, Instituto de Biociências, UNESP-Universidade Estadual Paulista “Julio de Mesquita Filho", Rua Prof. Dr. Antônio Celso Wagner Zanin, 250, 18618-0689, Botucatu, SP, Brazil.

J.M. Mirande. Fundación Miguel Lillo, Unidad Ejecutora Lillo-CONICET, San Miguel de Tucumán, 4000, Argentina.

F.R. Carvalho. Universidade Federal de Mato Grosso do Sul, Instituto de Biociências, Laboratório de Ictiologia, Av. Costa e Silva, s/n, Cidade Universitária, 79070-900, Campo Grande, MS, Brazil.

Corresponding author: Flávio C.T. Lima (email: fctlima@gmail.com).

Copyright remains with the author(s) or their institution(s). Permission for reuse (free in most cases) can be obtained from copyright.com. 
Fig. 1. Pristella crinogi sp. nov.: (A) holotype, ZUEC 17252, female, $19.2 \mathrm{~mm}$ standard length (SL), Brazil, Tocantins, Mateiros, ribeirão Brejão; (B) paratype, ZUEC 17253, male, $17.3 \mathrm{~mm}$ SL, same data as holotype. Figure courtesy of E.G. Baena. Color version online.

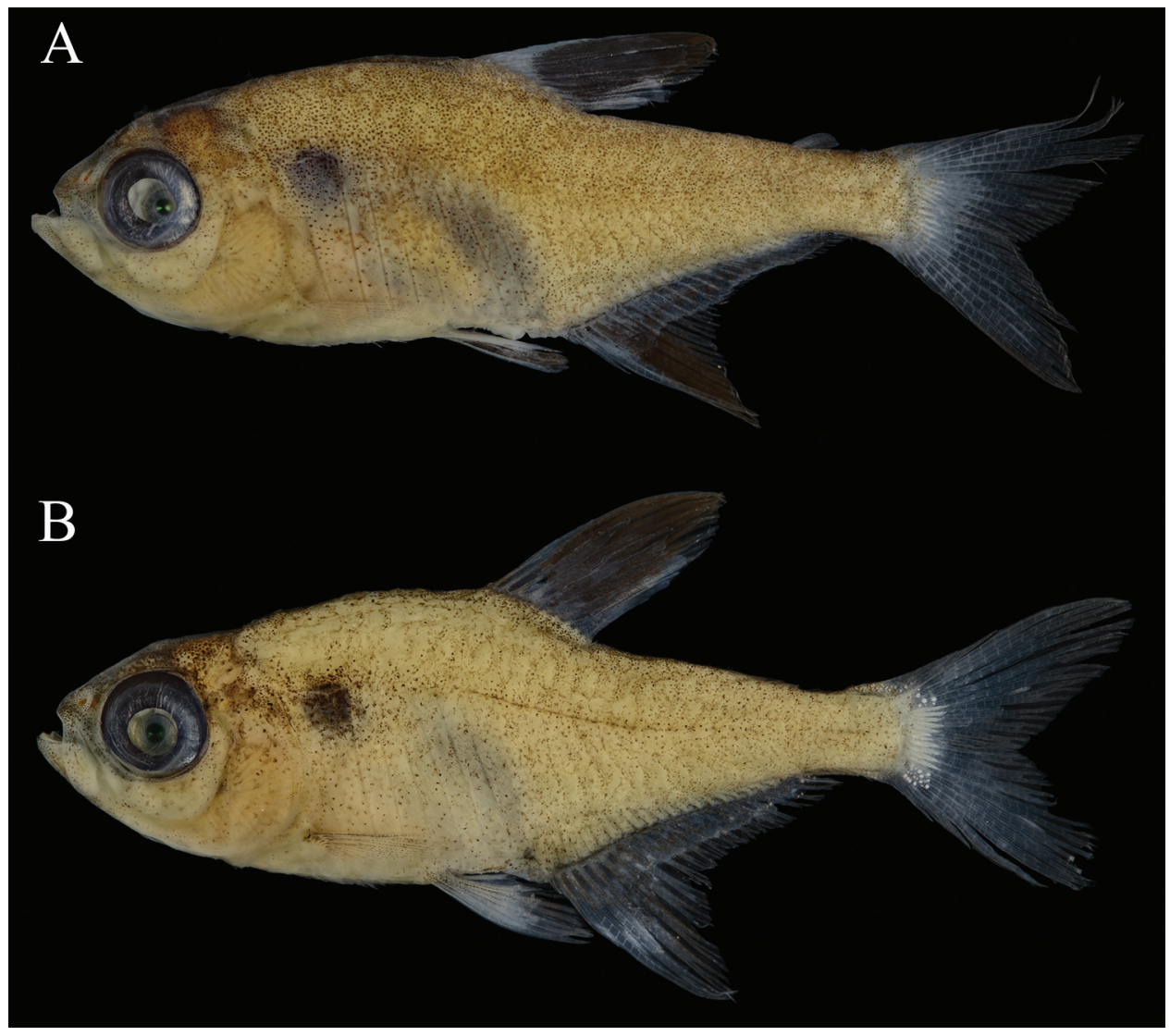

exception of the scale rows below the lateral line, which were counted to the insertion of pelvic fin. The count of horizontal scale rows between the dorsal-fin origin and the lateral line does not include the scale of the median predorsal series situated just anterior to the first dorsal-fin ray. In the description, the frequency of each count is given in parentheses after the respective count and an asterisk indicates the count of the holotype. Numbers of supraneurals, vertebrae, procurrent caudal-fin rays, unbranched dorsal- and anal-fin rays, branchiostegal rays, and gill rakers were taken only from cleared and stained paratypes (cs), prepared according to Taylor and Van Dyke (1985). Vertebrae of the Weberian apparatus were counted as four elements, and the fused PU1+U1 of the caudal region were counted as a single element. In the list of material examined, the total number of specimens in the lot is followed by the number of those cleared and stained (if any). Institutional abbreviations follow Sabaj (2019).

Phylogenetic relationships of the new taxon were evaluated through a comprehensive phylogenetic analysis of the Characidae, combining 520 morphological characters and 9 molecular markers. Since its first proposal (Mirande 2009), the analyzed dataset was progressively augmented and curated to some of the latest phylogenetic approaches for the Characidae (i.e., Conde-Saldaña et al. 2019; Ohara et al. 2017, 2019; Terán et al. 2020). In its present form, it includes 596 species representing all characiform families and characid subfamilies. The morphological partition of the dataset was coded for 344 terminals including the new species herein described. Molecular partitions are the same analyzed by Terán et al. (2020), who listed the corresponding GenBank accession numbers. Parsimony analyses were done under extended implied weighting (Goloboff 1993, 2014) with TNT software (Goloboff et al. 2008). Molecular characters were collectively weighted according to the average homoplasy of, either, 30 contiguous sites (GRO) or entire partitions of data (BLK) (details in Mirande 2017, 2019; Terán et al. 2020). Analyses were ran in a broad range of concavity constants involving $9 \mathrm{~K}$ values for each of these weighting schemes, totalling, thus, 18 weighting conditions (for details see Goloboff 1993, 2014; Mirande 2009, 2017, 2019; Terán et al. 2020). Different analytical conditions are denoted with its weighting scheme followed by its weighting strength against homoplasy (K value). For instance, GRO25 means collective weighting by the average homoplasy of 30 contiguous sites on molecular partitions, using a $K$ value of 25 . Searches were done initially on each weighting condition by separate, using sectorial searches, tree drifting, and tree fusing (Goloboff 1999; Nixon 1999). After that, several rounds of tree fusing were done (Goloboff 1999) from the (at least temporarily) optimal hypotheses for all analytical conditions. This procedure was repeated until no further improvements were obtained in any analytical condition. The final hypothesis was selected as the overall most parsimonious among the ones obtained in the explored parameters (for details see Terán et al. 2020). In a set of trees, each one optimal under different analytical conditions, this criterion will prefer the one that is, on average, the closest possible to be optimal in the whole set of explored conditions over the trees that are usually far to be optimal excepting for some specific set of parameters. In other words, we prefer the most parsimonious trees that are robust to variations in the analytical conditions, in an analog way we have more confidence in the monophyly of stable clades than on groups of species that are monophyletic only under specific analytical conditions (Giribet 2003). Support was calculated through symmetric resampling (probability of change 0.33), searching with sectorial searches, and tree fusing on each resampled matrix (Goloboff 1999). Two different resampling strategies were 
Fig. 2. Pristella crinogi sp. nov., living female specimen, collected with holotype (standard length unrecorded). Figure courtesy of M. Taylor.



conducted, using different parameters, one of them after 100 pseudoreplicates and rather intensive searches on each resampled matrix ("level 3" of TNT) and the other after 300 pseudoreplicates and shallower searches ("level 1" of TNT). As usually the error in the calculation of support by resampling methods is by underestimation, the highest value obtained for each node after the two strategies was used. Results are expressed as GC values (differences of frequencies "group present/contradicted"; Goloboff et al. 2003) calculated on the consensus of the most parsimonious trees. The morphological partition of the dataset, the combined matrix, and the consensus of the most parsimonious trees obtained both under implied and equal weighting are available online at MorphoBank P3819 (O'Leary and Kaufman 2011).

\section{Results}

Pristella crinogi sp. nov.

Figs. 1A, 1B, and 2; Table 1

Hyphessobrycon sp. "vermelhinho": Lima and Caires 2011: 239, 243, 245, 249 (Brazil, Tocantins, Mateiros, Ribeirão Brejão, tributary of rio Preto, rio Tocantins basin).

ZOOBANK LSID: urn:Isid:zoobank.org:act:32D618F1-30DA-4BC8-BC43525B40A68DAA.

ноLотуре: ZUEC 17252 (1 specimen, female, $19.2 \mathrm{~mm}$ SL): Brazil, Tocantins, Mateiros, ribeirão Brejão, tributary of rio Preto (rio Tocantins basin), $10^{\circ} 34^{\prime} 29^{\prime \prime} \mathrm{S}, 46^{\circ} 29^{\prime} 13^{\prime \prime} \mathrm{W}$; C. Oliveira, M. Taylor, B.F. Melo, and G.S.C. Silva, 12 Aug. 2014.

PARATYPES: All from Brazil. Tocantins, rio Tocantins basin: LBP 19057 (8 specimens; 1 unsexed juvenile, 9.0 mm SL; 5 males, 13.5-18.5 mm SL; 2 females, $12.9-16.5 \mathrm{~mm} \mathrm{SL} ; 1$ male $17.0 \mathrm{~mm} \mathrm{SL}$, cs); ZUEC 17253 (6 specimens; 1 unsexed juvenile, $10.6 \mathrm{~mm}$ SL; 3 males, 15.8-18.3 mm SL; 2 females, 12.9-18.3 mm SL; 1 female $18.3 \mathrm{~mm} \mathrm{SL}, \mathrm{cs}$ ): same data as holotype. ANSP 207541 (2 specimens; 1 male, 15.6 mm SL; 1 female, $16.4 \mathrm{~mm} \mathrm{SL}$ ); CAS 247240 (2 specimens; 1 male, 15.9 mm SL; 1 female, 14.7 mm SL); FMNH 144979 (2 specimens; 1 male, 14.4 mm SL; 1 female, 15.6 mm SL); MZUSP 98514 (18 specimens; 9 females, 10.3-14.5 mm SL; 7 males, 14.4-17.4 $\mathrm{mm} \mathrm{SL} ; 1$ male, $16.1 \mathrm{~mm}$ SL and 1 female, $15.5 \mathrm{~mm} \mathrm{SL}$, cs): ribeirão Brejão, tributary of rio Preto, $10^{\circ} 34^{\prime} 29^{\prime \prime} \mathrm{S}, 46^{\circ} 29^{\prime} 12^{\prime \prime} \mathrm{W}$; F.C.T. Lima, R.A. Caires, and C. Nogueira, 1-3 Feb. 2008. Bahia, rio São Francisco basin: LBP 28159 (2 specimens; 1 male, 15.8 mm SL; 1 female, $15.1 \mathrm{~mm} \mathrm{SL})$ : Formosa do Rio Preto, rio Sapão, $10^{\circ} 44^{\prime} 44^{\prime \prime}$,
Table 1. Morphometric data for holotype and paratypes of Pristella crinogi sp. nov. from the rio Tocantins basin.

\begin{tabular}{llllll}
\hline & Holotype & Paratypes & Mean & SD & $n$ \\
\hline Standard length (mm) & 19.2 & $12.9-19.2$ & 15.8 & - & 34 \\
Percentage of standard length & & & & & \\
$\quad$ Depth at dorsal-fin origin & 31.3 & $30.3-39.2$ & 35.4 & 2.6 & 34 \\
Snout to dorsal-fin origin & 47.4 & $47.4-55.4$ & 52.6 & 2.1 & 34 \\
Snout to pelvic-fin insertion & 42.2 & $42.2-50.4$ & 47.2 & 1.9 & 34 \\
Snout to anal-fin origin & 60.4 & $56.1-63.6$ & 59.9 & 1.7 & 32 \\
Dorsal-fin base length & 13.0 & $13.0-17.0$ & 14.7 & 0.9 & 34 \\
Dorsal-fin height & 28.1 & $25.6-32.0$ & 29.1 & 1.7 & 34 \\
Pectoral-fin length & 17.7 & $13.4-21.5$ & 17.4 & 1.8 & 20 \\
Pelvic-fin length & 16.7 & $16.7-22.0$ & 18.9 & 1.5 & 34 \\
Anal-fin base length & 28.6 & $27.7-33.5$ & 30.8 & 1.6 & 34 \\
Anal-fin lobe length & 25.5 & $20.2-28.7$ & 25.2 & 2.0 & 31 \\
Caudal peduncle depth & 8.9 & $6.4-12.1$ & 10.0 & 1.6 & 34 \\
Caudal peduncle length & 13.0 & $12.3-19.4$ & 15.4 & 1.4 & 34 \\
Head length & 28.6 & $28.1-33.3$ & 30.8 & 1.3 & 34 \\
Percentage of head length & & & & & \\
Horizontal eye diameter & 41.8 & $39.7-48.1$ & 44.0 & 1.9 & 34 \\
Snout length & 18.2 & $18.2-26.2$ & 22.6 & 2.2 & 34 \\
Least interorbital width & 23.6 & $23.0-33.5$ & 29.1 & 3.2 & 34 \\
Upper jaw length & 40.0 & $35.3-44.4$ & 40.0 & 2.0 & 34 \\
\hline
\end{tabular}

Note: SD, standard deviation; $n$, number of examined types, including the holotype.

$46^{\circ} 11^{\prime} 46^{\prime \prime}$ W; B.F. Melo, R. Devidé, C. Conde-Saldaña, and C. Araya, 14 Oct. 2018.

NOT-TYPE: LBP 28298 (1 specimen, female, $21.7 \mathrm{~mm}$ SL): Brazil, Minas Gerais, João Pinheiro, rio da Prata (lagoons), rio Paracatu basin, $17^{\circ} 32^{\prime} 47^{\prime \prime} \mathrm{S}, 46^{\circ} 27^{\prime} 13^{\prime \prime} \mathrm{W}$; B.F. Melo, G.S.C. Silva, R. Devidé, and L.H. Silva, 15 Jan. 2019.

DIAGNOSIS: Pristella crinogi can be distinguished from P. maxillaris by the following combination of characters: presence of 2-4 maxillary teeth (vs. 14-22 maxillary teeth present); all teeth of the premaxilla and dentary conical (vs. larger teeth of the premaxilla and dentary tricuspid; Fig. 3); presence of a dark pigmentation on the pelvic fin only in females (vs. small dark blotch on the pelvic fin present in both males and females); humeral blotch absent (vs. small humeral blotch present), presence of an elongated vertically oriented blotch at the anteriormost portion of anal fin in females (vs. roughly square dark blotch at the anteriormost portion of anal fin in both sexes); and presence of an overall reddish 
Fig. 3. Premaxilla, maxilla, and lower jaw of Pristella crinogi sp. nov., MZUSP 98514, $15.5 \mathrm{~mm}$ SL, left side, in outer view. Scale bar = $0.02 \mathrm{~cm}$.

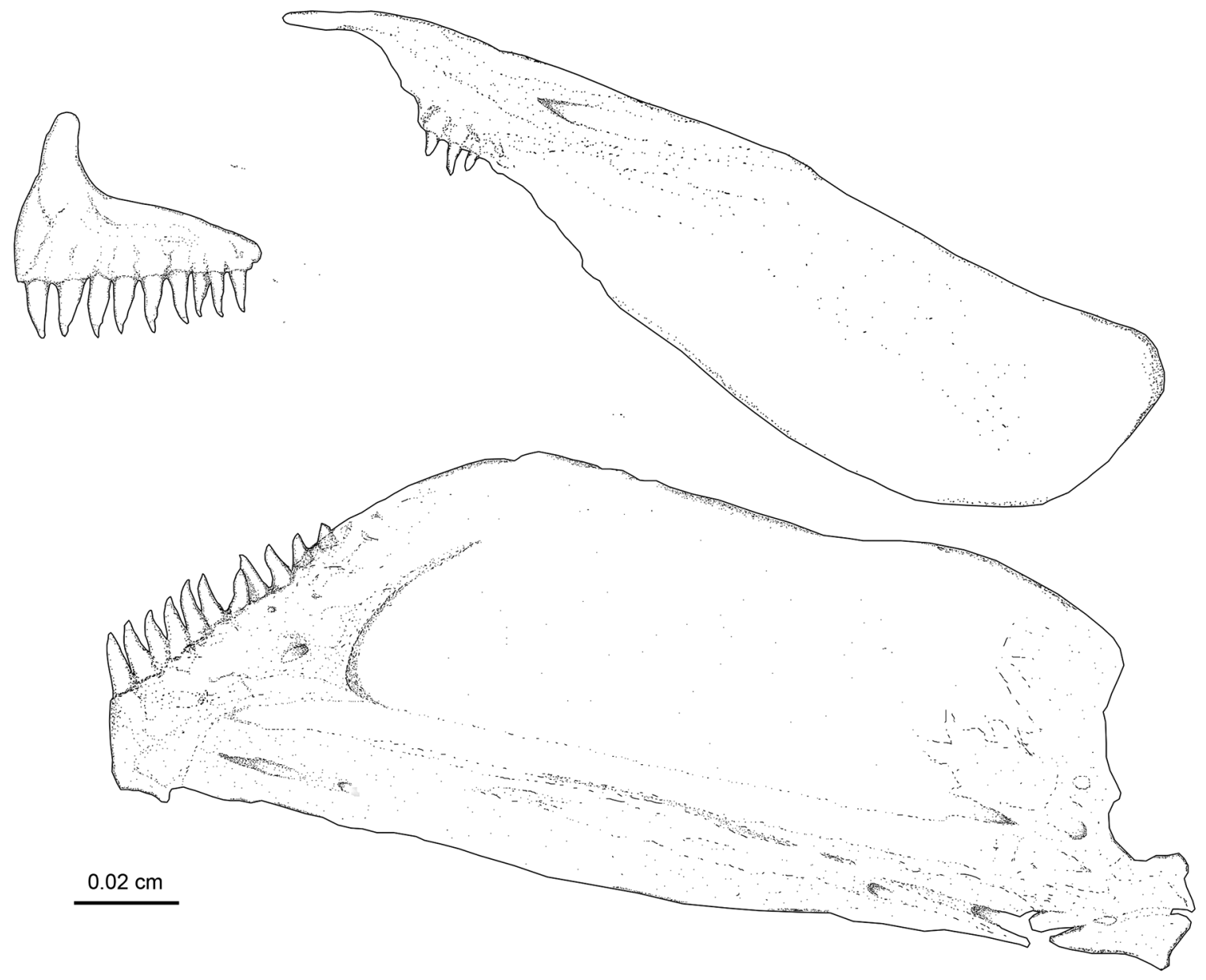

color pattern in live specimens, with head and caudal fin deep red (vs. overall color pattern clear, only caudal fin with reddish pigmentation). Pristella crinogi can be further distinguished from $P$. ariporo by presenting 2-4 maxillary teeth (vs. maxillary edentulous), by having a more developed dark blotch at the dorsal fin, extending from middle to distal portions of last unbranched to anteriormost seven branched rays (vs. relatively small dark blotch at the dorsal fin, extending from middle to distal portions of last unbranched to anteriormost four branched rays), by the presence of a conspicuous dark pigmentation on the pelvic fins in females (vs. conspicuous dark pigmentation at pelvic fin absent in both sexes), and by the presence of an elongated vertically oriented blotch at the anteriormost portion the anal fin in females more developed, extending to the tip of the fin lobe (vs. elongated vertically oriented blotch at the anteriormost portion the anal fin in females relatively small, not extending into the tip of the anal-fin lobe).

Pristella crinogi is similar in overall color pattern to the Hyphessobrycon species of the "rosy tetra clade" (sensu Weitzman and Palmer 1997). It can be distinguished from all species suggested to belong to this clade by Weitzman and Palmer (1997), except Hyphessobrycon axelrodi (Travassos, 1959), by the combination of a single row of premaxillary teeth (vs. two rows of premaxillary teeth in the majority of the species assigned to the rosy tetra clade) and teeth of the premaxillary and dentary all conical and similar in size (vs. larger teeth of the premaxillary and dentary with, at least, three cuspids). Pristella crinogi can be distinguished from $H$. axelrodi by at least two features of the females: the possession of an elongated, vertically oriented blotch at the anteriormost portion of the anal fin (vs. dark pigmentation at the anterior portion of the fin restricted to a small blotch) and the presence of a conspicuous dark pigmentation on the pelvic fins in females (vs. conspicuous dark pigmentation at pelvic fin absent in both sexes). See the Discussion for more comments on $H$. axelrodi.

DESCRIPTION: Morphometric data for holotype and paratypes in Table 1. Body compressed, moderately high. Greatest body depth at vertical through dorsal-fin origin. Dorsal profile of head straight to slightly concave from upper lip to vertical through middle of orbit, straight to slightly convex from that point to posterior tip of supraoccipital spine. Dorsal profile of body slightly convex from supraoccipital spine tip to dorsal-fin origin. Dorsalfin base straight to slightly convex, posteroventrally slanted, approximately straight from posterior terminus of dorsal fin to adipose-fin insertion, and slightly concave between adipose-fin insertion and origin of anteriormost dorsal procurrent caudal-fin ray. Ventral profile of head and body convex from tip of lower jaw to anal-fin origin. Anal-fin base straight, posterodorsally slanted. Ventral profile of caudal peduncle slightly concave.

Jaws unequal, dentary extending slightly beyond premaxilla, mouth slightly upturned. Posterior terminus of maxilla reaching vertical through anterior margin of eye. Nostrils close to each other, anterior opening round, posterior opening elliptical. Frontals not united anteriorly, with wide triangular frontal fontanel; parietal fontanel large, extending from epiphyseal bar to supraoccipital spine. Infraorbital series with three elements: 1-3. Laterosensory canal 
absent on infraorbitals. Third infraorbital largest and contacting the laterosensory canal of preopercle ventrolaterally.

Premaxillary teeth in single row, with 8(7), 9(14), 10(2), or 11(1) conical teeth. Maxilla with 2(9), 3(13), or 4(1) conical teeth. Dentary with 10(3), 11(3), 12(6), 13(9), 14(1), 15(1), or 18(1) conical teeth, anteriormost teeth larger, teeth decreasing gradually in size towards posterior portion of dentary (Fig. 3).

Scales cycloid. Three to five radii strongly marked, circuli wellmarked anteriorly, absent posteriorly. Lateral line slightly deflected downward and incompletely pored, with 4(11) or 5*(23) perforated scales. Longitudinal scale series including lateral-line scales 29(6), $30(8), 31^{*}(12), 32(6)$, or 33(2). Longitudinal scale rows between dorsal-fin origin and lateral line $5^{*}(24)$ or $6(9)$. Longitudinal scale rows between lateral line and pelvic-fin origin $3^{*}(16)$, or $4(18)$. Scales in median series between tip of supraoccipital and dorsal-fin origin 7(11), 8*(19), or 9(4). Scale sheath along anal-fin base formed by 24 scales in single row. Circumpeduncular scales 10*(5), 11(12), or 12(19). Caudal fin lacking scales. Axillary scale absent.

Dorsal-fin rays ii, $8^{*}(3), 9(30)$, or $10(1)$. Dorsal-fin origin slightly anterior to middle of standard length. First dorsal-fin pterygiophore main body located posterior to neural spine of eighth (2) vertebrae. Anteriormost anal-fin pterygiophore inserting posterior to haemal spine of 13 th (1) or 14th (1) vertebrae. Anal-fin rays iii(2), or iv(2), $17(1), 18(5), 19(13)$, or $20^{*}(9)$, or $21(6)$. Last unbranched and first to third anteriormost branched rays distinctly longer than remaining rays, forming elongated lobe; subsequent rays gradually decreasing in size. Pectoral-fin rays i, 7(1), $8^{*}(8)$, or 9(13); rays absent in 26 females (10.3-16.4 mm SL), present in 4 females (15.1$19.2 \mathrm{~mm} \mathrm{SL}$ ). Pectoral fin in most females lacking fin rays and instead having a morphology similar to larval specimens, with most endoskeletal portions cartilaginous and some dermal bones undeveloped. Pelvic-fin rays i,6*(34). Tip of pelvic fin reaching anal-fin origin. Caudal fin forked, lobes roughly rounded, with $\mathrm{i}, 9 / 8, \mathrm{i}^{*}(21)$ rays. Adipose fin present and normally developed in 5 females and 2 males; vestigial in 4 females and 4 males; and absent in 7 females and 11 males. Eight (1), 9(2), or 10(1) dorsal procurrent caudal-fin rays, and 5(1), 6(1), 7(1), or 8(1) ventral procurrent caudal-fin rays.

Precaudal vertebrae 13(1) or 14(1) and caudal vertebrae 18(1) or 19(1). Total vertebrae 32(3) or 33(1). Supraneurals 4(4). Branchiostegal rays 4. First gill arch with 2(4) hypobranchial, 9(3), or 10(1) ceratobranchial, 1(4) on cartilage between ceratobranchial and epibranchial, and 6(4) epibranchial gill rakers. Pseudotympanum present, extended as a muscular hiatus anterior to first pleural rib. Dorsal margin of pseudotympanum limited by lateralis superficialis.

COLOR IN ALCOHOL: Overall ground coloration of head and body light beige (Figs. 1A and 1B). Dorsal portion of head and tip of dentary with relatively dense concentration of melanophores. Predorsal region and dorsal area between dorsal-fin terminus and anteriormost dorsal procurrent rays with moderate concentration of melanophores. Lateral portion of body above midline with melanophores either uniformly scattered or concentrated along scale margin. Diffuse, scattered melanophores along midline, especially posterior to vertical through dorsal-fin terminus, forming a broken line. Lateral side of head and abdominal region almost devoid of chromatophores. Some specimens (e.g., ZUEC 17252, holotype) with an overall denser concentration of melanophores over the sides of body. Opercle translucent. Dorsal fin with conspicuous dark blotch at middle to distal portion of last unbranched to anteriormost seven branched rays. Remaining portion of dorsal fin hyaline, with scattered dark chromatophores. Anal fin with conspicuous, vertically elongated dark blotch at middle portion of anteriormost three to four branched rays in females. Remaining portion of anal fin hyaline, with scattered dark chromatophores along fin rays. Pelvic fin with blurred dark pigmentation in females. Pectoral, pelvic, and caudal fins hyaline, with small scattered dark chromatophores next to rays.

COLOR IN LIFE: Based on Fig. 2, plus cursory examination of several living specimens by two of the authors (F.C.T.L. and R.A.C.) in the field. Overall color pattern reddish; head and anterior two-thirds of caudal fin deep red. Bases of dorsal and pelvic fins reddish. Black fin markings as in preserved specimens. A dark vertical bar at middle of eye.

SEXUAL DIMORPHISM: Females with elongated blotch at anteriormost branched anal-fin rays, extending from first to third branched rays, and similarly conspicuous stripe on pelvic fins (first to second branched ray), both of which are absent in males (compare Figs. $1 \mathrm{~A}$ and $1 \mathrm{~B}$ ). Additionally, mature males possess hooks on the pelvic and anal fins. Four hooks are present on the unbranched ray and in the anteriormost two branched rays of pelvic fin. Branched rays with hooks present only on posterior branch, with a single hook present per ray segment. Three to six hooks are present on the unbranched ray and anteriormost five branched rays of anal fin. Branched rays with hooks present only on posterior branches, with a single hook per ray segment. Additionally, males possess a slightly longer pelvic fin than females (respectively, 16.8\%-22.0\% SL and mean 19.7\% SL vs. 16.7\%-19.4\% SL and mean $17.9 \% \mathrm{SL})$.

DISTRIBUTION: Pristella crinogi is known from a small tributary of the rio Preto, itself a tributary of rio Novo, upper rio Tocantins basin, Tocantins State, from the shared headwaters between rio Sapão (rio São Francisco basin) and rio Novo (rio Tocantins basin), Bahia State, and also from the floodplains of a tributary of the middle rio São Francisco basin, Minas Gerais State, Brazil (Fig. 4).

ECOLOGICAL NOTES: The type locality of Pristella crinogi, the ribeirão Brejão (Fig. 5), is a narrow, shallow, clear water stream with sandy bottom and abundant aquatic vegetation, with a moderately developed riparian forest with many buriti (Mauritia flexuosa L.f.) palms. Specimens of $P$. crinogi were collected within the dense mats of aquatic vegetation. Stomach contents of two cs specimens contained insect remains (apparently Trichoptera larvae). Both males and females collected in February (late rainy season) were ripe. Males collected in August (late dry season) present fin hooks, but females were not obviously ripe (i.e. oocytes were not discernible through the abdominal wall).

етумоlogy: The specific epithet crinogi honors our dear friend, the herpetologist Cristiano de Campos Nogueira ("Crinog"), for his enthusiastic help during the fish survey at the Estação Ecológica Serra Geral do Tocantins in 2008 when the new species was discovered. A patronymic adjective.

REMARKS: Lot LBP 28298 was excluded from the type series because the specimen is in a bad state of conservation, dehydrated, with a twisted, fractured body, and broken fins.

PHYLOGENETIC RELATIONSHIPS: The same set of 81 most parsimonious trees of 72082 steps were obtained under GRO39-GRO41 (fit 953.76361 in GRO41), although the monophyly of Pristella and the relationships among its species were stable along all the explored analytical conditions (BLK and GRO with $K$ values of 20-56). Under all these parameters, P. maxillaris is the sister group of P. ariporo and P. crinogi. In the most parsimonious trees obtained in BLK20, BLK26, GRO20-GRO26, GRO35-GRO48, and GRO56, Pristella is the sister group of a clade composed of Bryconella pallidifrons (Fowler, 1946), Hemigrammus bellottii (Steindachner, 1882), and Hemigrammus 
Fig. 4. Map of upper and middle rio Tocantins and upper and middle rio São Francisco basins, Brazil, showing the known distribution of Pristella crinogi sp. nov. (red star denote type locality and red circles denote remaining known localities). The map was built using QGis (version 3.14) with the model of digital altitude Shuttle Radar Topography Mission (USGS) and the hydrography is modified from the project HydroSHEDS (WWF), and finalized in Inkscape (version 1.0). Figure courtesy of G.N. Salvador. Color version online.

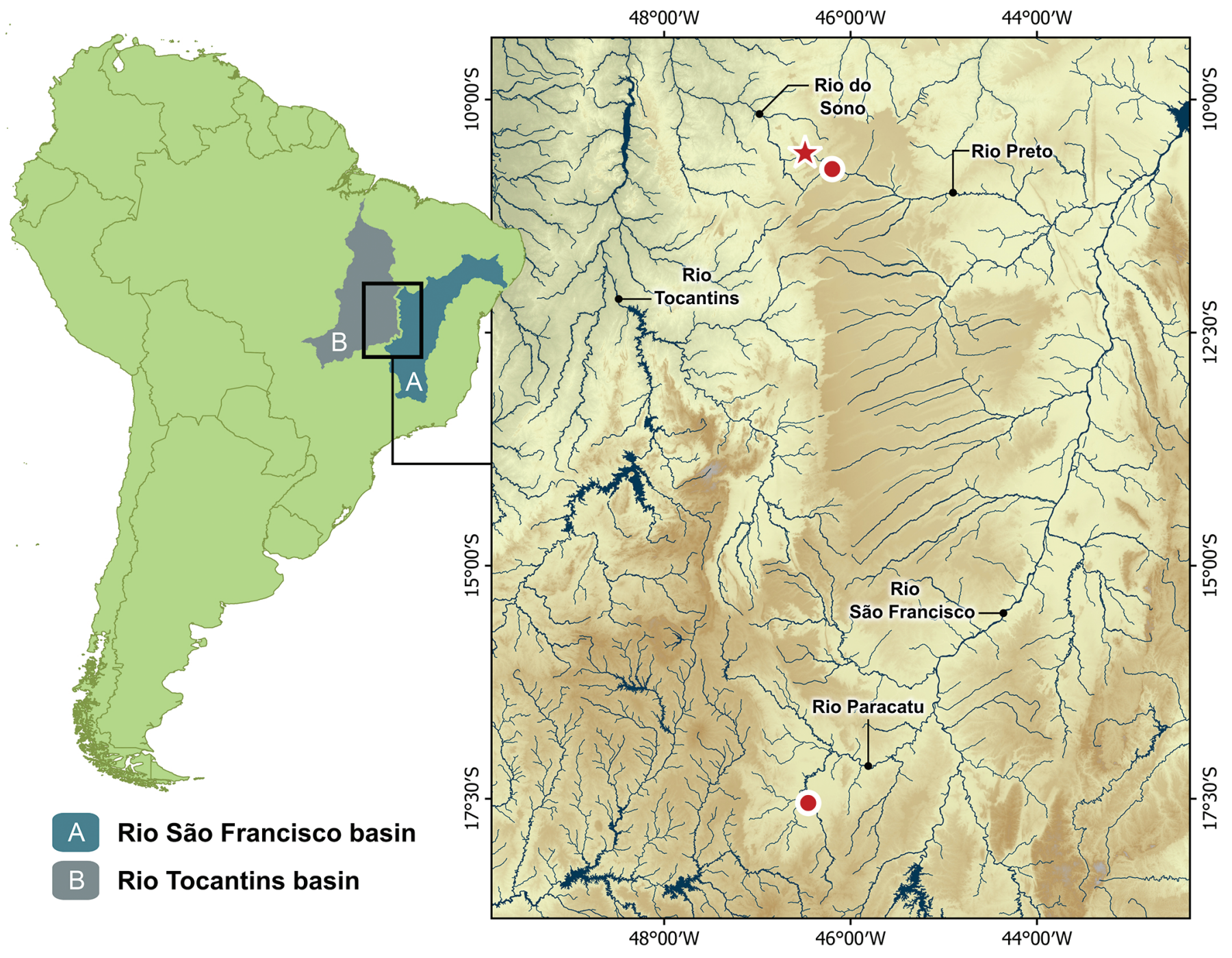

schmardae (Steindachner, 1882). In the remaining analytical conditions, the sister group of Pristella is B. pallidifrons.

According to the present analysis, Pristella is supported by 12 morphological synapomorphies: ethmoid cartilage reaching anteriorly lateral ethmoids (40:0), ventral ridge of prootic limiting auditory foramen posteriorly (55:1), first infraorbital reaching a position close to anterior margin of antorbital (79:1), absence of anguloarticular laterosensory canal (105:1), maxillary teeth predominantly conical (192:0), dentary teeth with three or fewer cusps (201:0), abrupt decrease in size of dentary teeth (207:1), foramen for pseudobranch artery as a canal piercing metapterygoid obliquely (228:1), posterior margin of opercle pronouncedly concave (252:1), pseudotympanum present (485:1), presence of a muscular hiatus anterior to rib of fifth vertebra (486:1), and presence of a dark spot on dorsal fin (496:1). The sister-group relationship between P. ariporo and P. crinogi is supported by five synapomorphies: absence of fourth, fifth, and sixth infraorbitals (90:1), dentary laterosensory canal restricted to anterior half of bone (103:1), six or fewer premaxillary teeth (183:0), i,6 pelvic-fin rays (384:0), and sclerotic bones paired (508:1).

The sister-group relationship between Pristella and the Bryconella clade is supported by 31 molecular synapomorphies plus 5 morphological ones: supraoccipital spine extended dorsally only to anterior axis of neural complex (62:1), subtemporal fossa not limited posteriorly by a prootic ridge (72:0), parietal branch of laterosensory canal completely absent (116:1; 117:1), reduced lateral urohyal expansions (305:1), and possession of 32 or less scales in lateral series (467:1).

\section{Discussion}

This contribution corroborates the monophyly and high support of Pristella and adds an additional species to the genus, being now composed of $P$. maxillaris, the type species of the genus as the sister group of $P$. ariporo and P. crinogi. The clade is included in the tribe Stethaprionini (Characidae: Stethaprioninae; Fig. 6). The present analysis partially supports the close relationship of Pristella with Bryconella obtained by Conde-Saldaña et al. (2019), given that in most analytical conditions, including our final hypothesis, B. pallidifrons forms a clade with $H$. bellottii and $H$. schmardae that is the sister group of Pristella. The support of the Bryconella clade, however, is low, which could be related to the lack of available molecular data for $\mathrm{H}$. bellottii and H. schmardae. The diagnosis of Pristella given by Conde-Saldaña et al. (2019) is still applicable 
with the inclusion of the new species: presence of one irregular row of mostly unicuspid premaxillary teeth (some tricuspid teeth in P. maxillaris), first infraorbital extended to anterior margin of antorbital, presence of a muscular hiatus anterior to first pleural rib, bony hooks on first pelvic-fin ray of males, and a dark blotch on the dorsal fin. The species of Pristella also share the presence of a gap between the infraorbital 3 and the preopercle, the SO5 laterosensory pore (sensu Pastana et al. 2020) oriented dorsomedially (see Mirande 2019: appendix S1, fig. 11C), the presence of nine branched dorsal-fin rays, and an interrupted lateral line. As mentioned by Conde-Saldaña et al. (2019), the diagnosis of Pristella may be complemented by some non-synapomorphic features: presence of a bony rhinosphenoid (character (ch.) 34, state 1; Mirande 2010: fig. 34); a conspicuous ethmopalatine cartilage (ch. 208, state 1); cartilage of first epibranchial articulating with anterior region of second pharyngobranchial (ch. 278, state 1; Mirande 2019: appendix S1, fig. 18B); up to four supraneurals (ch. 391, state 1); three rays articulating with first dorsal-fin pterygiophore, with the anteriormost minute and visible only in cs specimens (ch. 404, state 1); and presence of only one pair of uroneurals (ch. 427, state 0).

Among non-congeners, $P$. crinogi is remarkably similar to H. axelrodi, a species considered by Conde-Saldaña et al. (2019) as probably belonging to the genus Pristella. Hyphessobrycon axelrodi is to some extent even more similar to P. crinogi than to P. ariporo as it shares with the first species a similar maxillary dentition (compare Fig. 3 with figs. 2-3 in Travassos 1959). As noticed in the DIAGNOSIs above, $H$. axelrodi does not present the conspicuous dark markings in the pelvic and anal fins present in P. crinogi females. A full comparison between $H$. axelrodi and $P$. crinogi, as well as with the remaining Pristella species, and a reevaluation of its generic assignment must await for a redescription of this poorly known species.

The largest know specimen of $P$. crinogi reaches only $21.7 \mathrm{~mm} \mathrm{SL}$ (LBP 28298) and therefore this species should be considered a miniature following the criteria established in Weitzman and Vari (1988) and further discussed by Toledo-Piza et al. (2014). Additionally, the new species presents a set of reductive characters: loss of the fourth infraorbital bone and premaxillary teeth, dentary laterosensory canal restricted to anterior portion, undeveloped pectoral fin in females, and reduction or loss of adipose fin. The pectoral girdle is remarkable in $P$. crinogi because this structure is barely ossified in most females, with radials unossified and scapula cartilaginous, somewhat resembling the pectoral girdle observed in the paedomorphic characiforms of the genus Priocharax Weitzman and Vari, 1987 (Mattox et al. 2016), while all males possess large fins with ossified elements in the pectoral girdle. Pristella crinogi is polymorphic regarding the presence and relative development of the adipose fin, ranging from presenting a normally developed fin, a very reduced one, or entirely lacking it. Mattox et al. (2020) summarized the information concerning the loss of an adipose fin in characiform fishes and stated that, although this process is not always linked to miniaturization, size reduction is usually associated with the lack of adipose fin. They additionally discussed (p. 426) the condition present in some characiform fishes that, similarly to $P$. crinogi, display an intraspecific polymorphism in the presence/absence of the adipose fin.

The inference on truncated development of the pectoral girdle in P. crinogi females needs to be viewed with caution, since there is not an apparent change or loss of elements and, differently to the pectoral fin of Priocharax, the coracoid is ossified and the middle radials, albeit cartilaginous, are evident as separate elements. Also, the onset of pectoral-fin ossification is even later in ontogeny than the appearance of the adipose fin (Marinho 2017). On the other hand, the sexual dimorphism observed in the development of this structure for $P$. crinogi is remarkable and, given that $P$. crinogi individuals from both sexes are roughly the same size and possibly mature at the same age, it suggests a heterochrony of development in this species, with pectoral fins arising and
Fig. 5. Type locality of Pristella crinogi sp. nov.: Brazil, Tocantins, Mateiros, ribeirão Brejão, tributary of rio Preto, rio Tocantins basin. Color version online.

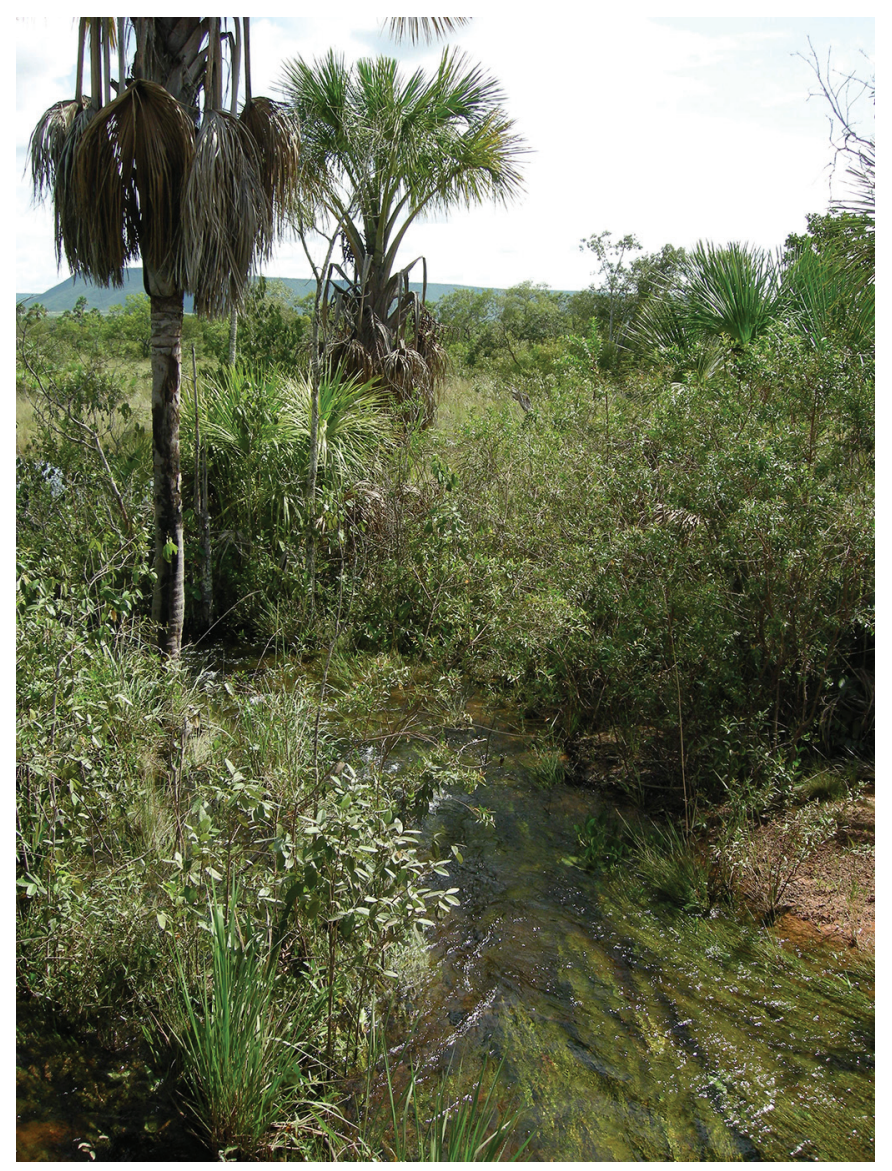

ossifying later in females, but information on ontogeny and lifespan to corroborate such assumption in the new species is still pending.

Pristella crinogi possess an unusual sexual dimorphism, as females possess dark markings on the anal and pelvic fins that are absent in the males. Pristella ariporo females also present black pigmentation on the anteriormost anal-fin rays, whereas males typically lack it (Conde-Saldaña et al. 2019: 443). Sexual dichromatism in characiforms was recently reviewed by Pastana et al. (2017). However, so far, in all characid species reported as presenting sexual dichromatism, males are more colorful than females (Pastana et al. 2017: 1312). Pristella crinogi and P. ariporo are the first known characiform fishes presenting a reversed sexual dimorphism, where the females possess a more developed color pattern than the males. This suggests a reversed role in mate choice in these species because the dimorphic color features present in males are usually related to attraction of females and intimidation of other males (Kodric-Brown 1998). The reversal of sexual dimorphism, where females present a more developed color pattern than males, are documented among bony fishes only for some syngnathids (Rosenqvist and Berglund 2011). Interestingly, P. maxillaris shares with P. crinogi the presence of dark pigmentation on the pelvic fins, and with both P. crinogi and P. ariporo the presence of a dark marking at the anteriormost anal-fin rays, but contrary to these species these color features are not dimorphic because they are present in both females and males.

The occurrence of P. crinogi in both the rio Tocantins and rio São Francisco basins is very interesting biogeographically because few species are shared between both basins (Lima and Caires 2011; 
Fig. 6. Phylogenetic relationships of the tribe Stethaprionini as obtained from the combined phylogenetic analysis under parsimony and extended implied weighting (GRO; $K=41$; fit $=953.76361$; length $=72082$ steps). Support is expressed as GC values (differences of frequencies "group present/contradicted"). Branch lengths represent graphically the number of synapomorphies. Color version online.

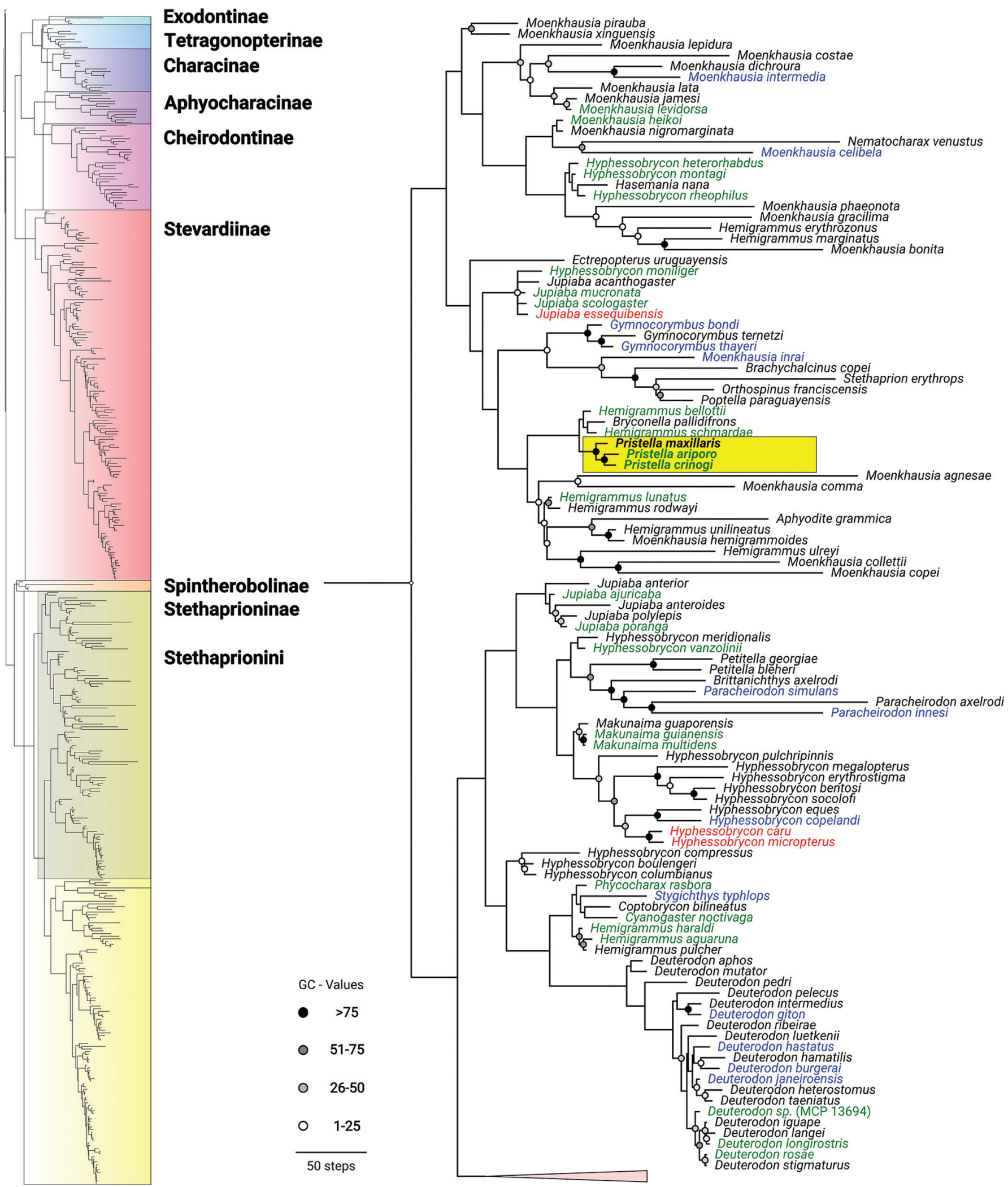


Dagosta et al. 2014). As discussed by Lima and Caires (2011), both basins are connected through the common headwater shared between the rio Novo (rio Tocantins basin) and the rio Sapão (rio São Francisco basin), but only the relatively few fish species occurring at this headwater area can effectively move from one basin into the other. The type locality of P. crinogi is within the rio Novo basin and the species was also collected at the common headwater between both basins. Additionally, and somewhat surprisingly, the species was recently collected at the floodplains of the rio Paracatu, a tributary of the middle rio São Francisco basin in Minas Gerais State, Brazil, roughly $750 \mathrm{~km}$ southward from the other localities from which P. crinogi is known (Fig. 4). This last record indicates a wide distribution of the species at the rio São Francisco basin, but we were unable to uncover any additional specimens of the species from this basin. The species most similar to $P$. crinogi occurring at the rio São Francisco basin is Hyphessobrycon micropterus (Eigenmann, 1915). This species can be readily diagnosed from $P$. crinogi by possessing a large, conspicuous dark humeral blotch (vs. humeral blotch absent in P. crinogi), anal fin with dark pigmentation at its distal portion in both males and females (vs. dark pigmentation in the anal fin as an elongated vertical blotch at anteriormost anal-fin rays, only in females), and larger dentary, premaxillary and maxillary teeth tricuspid (vs. all teeth unicuspid in P. crinogi). Hyphessobrycon micropterus has a relatively wide distribution in the rio São Francisco basin, and is recorded from the rio Sapão, very close to the locality from where P. crinogi is known (Lima and Caires 2011). It remains to be verified whether some of the lots currently identified as $\mathrm{H}$. micropterus in fish collections may contain specimens of P. crinogi.

The distribution of the genus Pristella is somewhat perplexing biogeographically. Pristella maxillaris is widely distributed along coastal river systems of northern cisandean South America, from the lower río Orinoco in Venezuela to the lower rio Tocantins basin in Brazil (Conde-Saldaña et al. 2019; Santos et al. 2004), being one of the fish species presenting the distribution pattern identified by Dagosta and de Pinna (2019: 24-25) as "Guiana Mangrove Province". Pristela crinogi and P. ariporo, despite being recovered herein as sister taxa, occur beyond the opposite ends of the distribution of $P$. maxillaris, i.e., the middle rio Tocantins and middle rio São Francisco basins and the llanos of the río Orinoco basin, respectively. Pristella crinogi occurs in relatively high areas (470$610 \mathrm{~m}$ above sea level) in the Brazilian shield, while P. ariporo and $P$. maxillaris occur at lowlands ( $<160 \mathrm{~m}$ above sea level). The occurrence of sister taxa with such disjunct distributions is very suggestive of a relictual distribution pattern because no historical biogeographical process can be invoked to have occurred between those geomorphological unrelated, distant areas.

COMPARATIVE MATERIAL EXAMinED: Additional to Conde-Saldaña et al. (2019). All from Brazil. Hyphessobrycon micropterus: CAS 98918, 6 paratypes, 21.3-23.7 mm SL, Minas Gerais, Pirapora, rio São Francisco basin; FMNH 57916, holotype, $23.5 \mathrm{~mm}$ SL, Bahia, rio São Francisco, Lagoa do Porto; FMNH 57917, 14 paratypes, 17.4-24.1 mm SL, same data as FMNH 57917; FMNH 57918, 9 paratypes, Bahia, Santa Rita, rio São Francisco; FMNH 57920, paratype, 20.8 mm SL, Bahia, rio Salitre; ZUEC 14676, 98 specimens, 17.0-27.9 mm SL: Minas Gerais, rio São Francisco basin.

\section{Acknowledgements}

We are grateful to C.C. Nogueira (MZUSP) for all his help during the expedition to the Estação Ecológica Serra Geral do Tocantins in February 2008 when the new species was discovered. Part of the material herein examined was kindly lent by C. Oliveira and B.F. Melo (LBP). We are grateful for E.G. Baena and G.N. Salvador for preparing Figs. $1 \mathrm{~A}$ and $1 \mathrm{~B}$ and Fig. 4, respectively. M. Taylor kindly provided Fig. 2. F.C.T.L. was funded by FAPESP (grants nos.
2007/02978-7, 2011/51532-7, and 2013/20936-0), project "Systematics of the tetras (genera Hemigrammus, Hyphessobrycon, Thayeria, Parapristella and Bryconella), with emphasis on the species of northern cisandean South America". R.A.C. is supported by FAPESP (grant No. 17/12909-4) and was funded by CNPq (grant No. 140053/2008-5). C.C.C-S. is funded by FAPESP (grant nos. 2018/09767-6 and 2019/16999-3). J.M.M. is funded by FONCyT (grant PICT-2016-0275) and permanently supported by Fundación Miguel Lillo and CONICET. F.R.C. is supported by CNPq (grant No. 420620/2018-4), FUNDECT (Fundação de Apoio ao Desenvolvimento do Ensino, Ciência e Tecnologia do Estado de Mato Grosso do Sul) (grant No. 59/300.093/2017, SIAFEM 27248) and received funding from FAPESP (grant nos. 2011/11422-8 and 2012/03404-2). TNT software was provided free by the Willi Hennig Society.

\section{References}

Conde-Saldaña, C.C., Albornoz-Gárzon, J.G., García-Melo, J.E., Villa-Navarro, F.A., Mirande, J.M., and Lima, F.C.T. 2019. A new Pristella (Characiformes: Characidae) from the Río Orinoco basin, Colombia, with a redefinition of the genus. Copeia, 107(3): 439-446. doi:10.1643/CI-18-147.

Dagosta, F.C.P., and de Pinna, M.C.C. 2019. The fishes of the Amazon: distribution and biogeographical patterns, with a comprehensive list of species. Bull. Am. Mus. Nat. Hist. 2019: 1-163. doi:10.1206/0003-0090.431.1.1.

Dagosta, F.C.P., Marinho, M.M.F., and Camelier, P. 2014. A new species of Hyphessobrycon Durbin (Characiformes: Characidae) from the middle rio São Francisco and middle rio Tocantins basins, Brazil, with comments on its biogeographic history. Neotrop. Ichthyol. 12(2): 365-375. doi:10.1590/ 1982-0224-20130179.

Eigenmann, C.H. 1908. Zoölogical results of the Thayer brazilian expedition. Preliminary descriptions of new genera and species of tetragonopterid characins. Bull. Mus. Comp. Zool. 52(6): 93-106.

Fink, W.L., and Weitzman, S.H. 1974. The so-called cheirodontin fishes of Central America with descriptions of two new species (Pisces: Characidae). Smithson. Contrib. Zool. 172: 1-46. doi:10.5479/si.00810282.172.

Giribet, G. 2003. Stability on phylogenetic formulations and its relationship with nodal support. Syst. Biol. 52: 554-564. doi:10.1080/10635150390223730. PMID:12857646.

Goloboff, P.A. 1993. Estimating character weights during tree search. Cladistics, 9: 83-91. doi:10.1111/j.1096-0031.1993.tb00209.x.

Goloboff, P.A. 1999. Analyzing large data sets in reasonable times: solutions for composite optima. Cladistics, 15: 415-428. doi:10.1111/j.1096-0031.1999. tb00278.x.

Goloboff, P.A. 2014. Extended implied weighting. Cladistics, 30: 260-272. doi:10.1111/cla.12047.

Goloboff, P.A., Farris, J.S., Källersjö, M., Oxelman, B., Ramıacuterez, M.J., and Szumik, C.A. 2003. Improvements to resampling measures of group support. Cladistics, 19: 324-332. doi:10.1111/j.1096-0031.2003.tb00376.x.

Goloboff, P.A., Farris, J.S., and Nixon, K.C. 2008. TNT, a free program for phylogenetic analysis. Cladistics, 24: 774-786. doi:10.1111/j.1096-0031.2008.00217.x.

Kodric-Brown, A. 1998. Sexual dimorphism and temporary color changes in the reproduction of fishes. Am. Zool. 38: 70-81. doi:10.1093/icb/38.1.70.

Lima, F.C.T., and Caires, R.A. 2011. Peixes da Estação Ecológica Serra Geral do Tocantins, bacias dos Rios Tocantins e São Francisco, com observações sobre as implicações biogeográficas das águas emendadas" dos Rios Sapão e Galheiros. Biota Neotrop. 11(1): 231-250. doi:10.1590/S1676-06032011000100024.

Marinho, M.M.F. 2017. Comparative development in Moenkhausia pittieri and Paracheirodon innesi (Ostariophysi: Characiformes) with comments on heterochrony and miniaturization in the Characidae. J. Fish Biol. 91: 851865. doi:10.1111/jfb.13384. PMID:28736894.

Mattox, G.M.T., Britz, R., and Toledo-Piza, M. 2016. Osteology of Priocharax and remarkable developmental truncation in a miniature Amazonian fish (Teleostei: Characiformes: Characidae). J. Morphol. 277: 65-85. doi:10.1002/ jmor.20477. PMID:26395188.

Mattox, G.M.T., Souza, C.S., Toledo-Piza, M., Britz, R., and Oliveira, C. 2020. A new miniature species of Priocharax (Teleostei: Characiformes: Characidae) from the Rio Madeira drainage, Brazil, with comments on the adipose fin in characiforms. Vert. Zool. 70(3): 417-433. doi:10.26049/ VZ70-3-2020-11.

Menezes, N.A., and Weitzman, S.H. 1990. Two new species of Mimagoniates (Teleostei: Characidae: Glandulocaudinae), their phylogeny and biogeography and a key to the glandulocaudin fishes of Brazil and Paraguay. Proc. Biol. Soc. Wash. 103(2): 380-426.

Mirande, J.M. 2009. Weighted parsimony phylogeny of the family Characidae (Teleostei: Characiformes). Cladistics, 25: 574-613. doi:10.1111/j.10960031.2009.00262.x.

Mirande, J.M. 2010. Phylogeny of the family Characidae (Teleostei: Characiformes): from characters to taxonomy. Neotrop. Ichthyol. 8: 385-568. doi:10.1590/S1679-62252010000300001. 
Mirande, J.M. 2017. Combined phylogeny of ray-finned fishes (Actinopterygii) and the use of morphological characters in large-scale analyses. Cladistics, 33: 333-350. doi:10.1111/cla.12171.

Mirande, J.M. 2019. Morphology, molecules and the phylogeny of Characidae (Teleostei, Characiformes). Cladistics, 35: 282-300. doi:10.1111/cla.12345.

Nixon, K.C. 1999. The parsimony ratchet, a new method for rapid parsimony analysis. Cladistics, 15: 407-414. doi:10.1111/j.1096-0031.1999.tb00277.x.

Nogueira, C.C., Ferreira, M.N., Recoder, R.S., Carmignotto, A.P., Valdujo, P.H., Lima, F.C.T., et al. 2011. Vertebrados da Estação Ecológica Serra Geral de Tocantins: faunística, biodiversidade e conservação no Cerrado brasileiro. Biota Neotrop. 11(1): 329-338. doi:10.1590/S1676-06032011000100030.

Ohara, W.M., Mirande, J.M., and Lima, F.C.T. 2017. Phycocharax rasbora, a new genus and species of Brazilian tetra (Characiformes: Characidae) from Serra do Cachimbo, rio Tapajós basin. PLoS ONE, 12(2): e0170648115. doi:10.1371/ journal.pone.0170648.

Ohara, W.M., Teixeira, T.F., Albornoz-Garzón, J.G., Mirande, J.M., and Lima, F.C.T. 2019. Hyphessobrycon rheophilus, a new species from rapids of the Amazon and Orinoco river basins (Characiformes: Characidae: Stethaprioninae). Zootaxa, 4712(4): 561-575. doi:10.11646/zootaxa.4712.4.5.

O'Leary, M.A., and Kaufman, S.G. 2011. MorphoBank: phylophenomics in the “cloud". Cladistics, 27: 529-529. doi:10.1111/j.1096-0031.2011.00355.x.

Pastana, M.N.L., Dagosta, F.C.P., and Esguícero, A.L.H. 2017. A new sexually dichromatic miniature Hyphessobrycon (Teleostei: Characiformes: Characidae) from the Rio Formiga, upper Rio Juruena basin, Mato Grosso, Brazil, with a review of sexual dichromatism in Characiformes. J. Fish Biol. 91(5): 1301-1308. doi:10.1111/jfb.13449. PMID:28905382.

Pastana, M.N.L., Bockmann, F.A., and Datovo, A. 2020. The cephalic lateralline system of Characiformes (Teleostei: Ostariophysi): anatomy and phylogenetic implications. Zool. J. Linn. Soc. 189(1): 1-46. doi:10.1093/ zoolinnean/zlz105.
Rosenqvist, G., and Berglund, A. 2011. Sexual signals and mating patterns in Syngnathidae. J. Fish Biol. 78: 1647-1661. doi:10.1111/j.1095-8649.2011.02972.x. PMID:21651521.

Sabaj, M.H., 2019. Standard symbolic codes for institutional resource collections in herpetology and ichthyology: an online reference. Version 7.1. American Society of Herpetologists and Ichthyologists, Washington, D.C. Available from https://asih.org/standard-symbolic-codes.

Santos, G.M., Mérona, B., Juras, A.A., and Jégu, M. 2004. Peixes do baixo rio Tocantins: 20 anos depois da Usina Hidrelétrica Tucuruí. Eletronorte, Brasília. pp. 1-215.

Taylor, W.R., and Van Dyke, G.C. 1985. Revised procedures for staining and clearing small fishes and other vertebrates for bone and cartilage study. Cybium, 9(2): 107-119.

Terán, G.E., Benitez, M.F., and Mirande, J.M. 2020. Opening the Trojan horse: phylogeny of Astyanax, two new genera and resurrection of Psalidodon (Teleostei: Characidae). Zool. J. Linn. Soc. 190(4): 1217-1234. doi:10.1093/zoolinnean/zlaa019.

Toledo-Piza, M., Mattox, G.M.T., and Britz, R. 2014. Priocharax nanus, a new miniature characid from the rio Negro, Amazon basin (Ostariophysi: Characiformes), with an updated list of miniature Neotropical freshwater fishes. Neotrop. Ichthyol. 12 (2): 229-246. doi:10.1590/1982-0224-20130171.

Travassos, H. 1959. A new species of characid fish from Trinidad, Aphyocharax axelrodi. Trop. Fish Hobb. 7(7): 5-7, 48-49.

Weitzman, S.H., and Palmer, L. 1997. A new species of Hyphessobrycon (Teleostei: Characidae) from the Neblina region of Venezuela and Brazil, with comments on the putative 'rosy tetra clade'. Ichthyol. Explor. Freshw. 7(3): 209-242.

Weitzman, S.H., and Vari, R.P. 1988. Miniaturization in South American freshwater fishes; an overview and discussion. Proc. Biol. Soc. Wash. 101: $444-465$. 